\title{
Exploring the Missing Gaps in the 1999 Constitution of Nigeria: A Review
}

\author{
George Anokwuru, Edmund Obomanu
}

Department of Political and Administrative Studies, University of Port Harcourt, Nigeria

\begin{abstract}
This paper explores the missing gaps in the 1999 Constitution of the Federal Republic of Nigeria to demonstrate evidence of adverse implications of the identified gaps on democracy transformation in Nigeria. The paper deploys a desk review methodology which draws from various relevant case examples and sections of the constitution and provides insights on some of the salient gaps in the constitution. The paper draws from the elite conspiracy theoretical framework and suggests that the constitution has been fundamentally contradictory and poorly directed at both the social and political realities of the country, which rarely constitute a marker of democratization since Nigeria's nascent democracy in 1999. The paper proposes a constitution review to urgently redress the identified lacuna and broaden the scope of the constitution in tandem with democratic ideals.
\end{abstract}

Keywords: Constitutional Gap, Governance, Democracy, Development, Nigeria

\section{INTRODUCTION}

Constitutional development is a dynamic process and as such susceptible to a number of short comings (Ezra 1964; Ikime 1980; Akande 1982; Udoma 1994; Odondiri, 2004). In the pre independence period Nigeria had many constitutions introduced by the colonial government. First was the Clifford Constitution of 1922, then, the Richards Constitution which came into force in 1946 and was suspended in 1950 while the McPherson and Littleton Constitutions were opened between 1951 and 1954 respectively.

In 1960, Nigeria adopted the Independence Constitution this was followed by some other post independence constitutions such as the 1963 republican constitution, the1979 constitution and the 1999 constitution respectively (FGN 1963; 1979; 1999).

Much of the post "Independence Nigeria was characterized by military interregnum, giving little or no room for constitutional practice. Since the fall of the first republic as a result of the first military coup in 1966, Nigeria experienced series of coups and counter coups giving rise to a thirty month civil war between 1968 to 1970.

In 1979 Nigerian adopted a presidential constitution following the Second republic which also came to an end with another coup in 1983. The Third Republic was aborted as a result of the annulment of the June $12^{\text {th }}$ Presidentialelection which created tension in the polity.

In 1999 Nigeria returned to civilian rule, with democracy as a system of government it retained the existing federal structure which implies the constitutional share of power between the centre and the federating component units.

The 1999 constitution was adopted and used as the supreme law of the state .A number of case scenarios and constitutional matters suggest that the 1999 constitution has a number of gaps which have been at issue in effective governance and politics in Nigeria. These constitutional loopholes which have not been given adequate scholarly attention remain the source of several controversies that continue to threaten political stability and democracy transformation in Nigeria.

Salient among them include but not limited to; Questions of citizenship/indigenship, power transition, power sharing, inter party conflict etc. These remain recurring issues which the Nigerian constitution is still grappling with.

These gaps point to the areas of weaknesses or flaws that contradict the desire and spirit of the constitution. The loopholes reveal what is termed a lacuna in legal parlance. These lacuna often 
reoccur in political practices and governance when they are rarely envisaged hence the need for a brief review.

The paper argues that these gaps have adverse implications on the quality of Nigeria's democracy and its deepening. It shows how these gaps reflect poor governance and political participation which contradicts the ideals of democracy. Relevant case examples were explored to provide fuller insights and broader elucidation of some of the salient gaps identified in the constitution. The rest of the paper is structured as follows; materials and methods, brief overview of the 1999 constitution, evidence of some constitutional gaps and case examples, finally conclusion.

\section{Materials AND Methods}

This study is a desk review which builds on secondary data sources. This methodology is suitable as it provides in-depth review of some of the key issues that suggest the existence of gaps in the 1999 constitution of Nigeria. The desk records emanated from the relevant sections of the 1999, partly 1979 and 1963 constitutions of the Federal Republic of Nigeria

The study will provide evidence-based events and trends in the Nigerian polity suggestive of these constitutional gaps using some case examples. Some of the evidence include; gender disparity; citizenship/indigenship crisis; the case of Anzaku \& 33 others v Ex.Gov NASG \& 2 ORS ; the question of prohibition; sexual discrimination; right to dignity of womanhood; federal character principle, ;right to inheritance, land use act etc.

There are also some important case examples to buttress gaps in the Nigerian constitution notably the case of Yar'A duah's Ill Health and constitutional Loophole; the case of the death of Abubakar Audu and constitutional gap; the case of Waziri Tambuwal's Defection.

The evidence based events and case examples are useful methodologies which provide clearer understanding of these gaps and broader elucidation of their implications to Nigeria's democracy. The methodology equally aims to identify and analyze relevant theoretical literature (books and journals, newspaper publications; conferences, reports) on the subject and essentially on the perspectives of stakeholders in contemporary Nigerian politics and governance.

This suggests alternative policy options to redress the problems emanating from the gaps identified. It further strengthens the understanding of the dialectical interface of constitutional gaps to re-occurring political problems of Nigeria both from opposing and proposing views.

Regarding the theoretical framework, the paper adopted the conspiracy theoretical framework. Conspiracy theorists (Popper, 1945; Wood, 1982; Barkun, 2003; Basham, 2011) argue that an "event or phenomenon occurs as a result of a conspiracy between interested parties; this involves an influential group or agency ".

In the making of the 1999 constitution there may have been some conspiracy by the framers of the constitution to maintain the status quo including some existing social practices or to serve the interest of a political class, in this particular case- the military. Karl Popper (1945) argued that conspiracy do exist and contends that they are typical social phenomena and argues that often times in the long run few of the conspiracies are ultimately successful.

In the particular Nigerian context the 1999 constitution has been largely criticized as a military invention thus framed to serve and protect the interest of the military and similar elites. Thus the conspiracy theory suitably reveals how the elite crafted the constitution to suit their interests.

More so, as Africa's largest democracy, understanding of the dynamics of constitutional politics and governance is critical to policy makers and researchers seeking for effective constitutional mechanisms.

The paper will explore causal linkages of these relevant case examples and events including actors as well as evidence based analysis to establish and interrogate the fundamental issues suggestive of constitutional gaps in Nigeria's nascent democracy. It seeks to advance understanding of how nascent democracy could be consolidated with dynamics of constitutionalism especially in the developing democracies such as Nigeria. This option to link democracy with constitutionalism has been critical but scant in Third World democracy studies. It has constituted a major problem in governance failure and challenge to the democratization process of Nigeria. This in our views has fundamental political and economic relevance in constitutional democracy. What follows is a brief overview on the 1999constitution, the identified gaps and case examples. 


\section{BRIEF OVERVIEW ON THE 1999 CONSTITUTION}

Nigeria is a federal system which operates a written constitution which constitutes the supreme law of the land. The country is presently governed by the 1999 constitution but recent political happenings in the country perhaps show that the country is far from being governed by any law.

The constitution was adopted on 29 May, 1999. It has 320 sections divided into 8 chapters and 15 parts with 7 schedules.

Chapter1 deals with the general provision which introduces to the reader to the sovereign state called Federal Republic of Nigeria said to be indivisible and indissoluble(no matter what), a federation consisting of 36 states a federal capital territory and Local Government Areas totaling 774 and 6 Area councils(FGN 1999).

The government consists of the Legislature, Executive and Judiciary. The legislative power of the federal republic as stated in Section 4shall be vested in the National Assembly of the federation made up the Senate and a House of Representatives which shall have powers to make laws for the peace, order and good governance of the federation or any part there- of with respect to any matter set out with exclusive legislative list as contained in the second schedule to the constitution part 1 thereof to the House of Assembly of States (FGN 1999).

Additionally, the National Assembly is also conferred with powers to make laws on any matter in the concurrent legislative list, set out in part 11 of the second schedule or any matter the constitution empowers it Under section 4(5) where a law enacted by the House of Assembly of a State is inconsistent with that made by the National Assembly; the later shall prevail and the State Assembly shall to the extent of the inconsistency be void (FGN1999).

In Section 5; the President holds executive powers while those of the state are vested in the Governor both of whom may exercise the powers themselves or assign their Vice and Ministers in case of the president and deputy Governor and Commissioner in the case of the Governor(FGN1999) .

Section 5(3)(a) Subject the exercise of the executive powers of the state to the exercise of the executive powers of the federation which it cannot impede or prejudice, whose asset or investment cannot be endangered or the continuance of which as a whole cannot be endangered(FGN1999).

Despite this provision, actual practice of the Nigerian constitution produces different outcome, a fact made evident by the myriad loopholes created by the constitution itself. Case examples of some of the constitutional gaps follow below.

\section{Evidence of Some Constitutional GAPS AND CASE EXAMPles}

\subsection{Gender Disparity}

In the 1999 constitution, gender disparity is discernible. For instance, in section 26(2)(a)and 29(4)(b) the word women was not often used unlike gender which was largely used in the entire section pointing to the marginalization of the word women and gender equality.

\subsection{Citizenship/Indigenship Crisis}

There is one phrase whose exact denotation is problematic namely: indigenous to: which was first used in the Constitution of the Federal Republic of Nigeria (CFRN) 1979.The term was not properly spelt out in the 1999 constitution and it has often created problems in understanding and delineating who is an indigene and who is not beyond that what should be considered in the context of indigeneity and what should not

Again, there is a lacuna on aspects of citizenship involving male foreigners married to Nigerian women and wishing to gain Nigerian citizenship .Section 26 defined a Nigerian citizen and process of citizenship by naturalization and registration, however the silence about the process of citizenship for non - Nigerian men perhaps results in challenges of marriage instability.

\subsection{The Case of Anzaku \& 33 others v Ex.Gov NASG \& 2 ORS}

There was a breach of constitutional provision on the issue on indegenship. This event took place in December 2004 in Jos North central Nigeria where the Appeal court Jos Division ruled that the Nassarawa state government acted in error in deploying a local government Staff to the alleged local government of origin. The court ruled that this was discriminatory and at variance with section 42 and 46 of the constitution of the federal republic of Nigeria. 
The Nigerian democratic constitution in its language exhibits how much value it places on the worth of each and every one of its citizens. it does not and will not condone indeed(will)not tolerate class or ethnic, etc discrimination whether by any law of the land or any action on the part of any executive or administrative authority or person or the state in sharing advantage and even disadvantages based on sex, race, place of origin ethnic, religious or political affiliation.

Other missing gaps in the Nigerian constitution include but not limited to the question of prohibition; Sexual Discrimination; The Federal character Principle; Right to inheritance

Prohibition: The term remains rather vague and indistinct in the constitution and often seen as a stand- alone phrase that may prove difficult and contradictory in practical terms

Sexual Discrimination: This is another term in the constitutional that has been poorly implemented in practical terms The right to dignity of womanhood has also been poorly internalized and implemented in the Nigerian constitution as women and their rights have been marginalized

The Federal Character Principle: This is an invention of the 1999 constitution aimed to reflect federal presence in all aspects of events or activities such as political offices, including the composition of the national football team However since its adoption the federal character principle has not enthroned ethnic emancipation both in the structure of political appointments and similar public offices

Right to Inheritance: In the 199 there is a gap in contextual application of the clause right to inheritance much of the crisis is reflective of persisted quarrels among families on the demise of its breadwinners

The Land Use Act: This has been a colonial legacy and often equates land grab and alienation It extends beyond the use of land alone rather encompasses the natural resources therein In the particular case of the oil rich Niger Delta there are repeated incidence of resource marginalization as constitutional dictates are not followed. There are other key issues that require urgent attention such as sexual discrimination, section 42(1-3);right to dignity of womanhood, section 34,their political and economic rights, section 14(3);right to inheritance, land use act etc. Equally there are important case examples to buttress gaps in the Nigerian constitution as follows;

\subsection{The Case of Yar'A duah's III Health and Constitutional Loophole}

Umaru Musa Yar'A duah was the President of the fifth republic and suddenly took ill while in office. His prolonged absence from Nigeria for reasons of illness, without constitutional transfer of power and authority to Dr Good luck Jonathan the Vice President to act on his behalf revealed a major constitutional lacuna in the Nigerian constitution and threatened the nation's political authority. Where- as, the provisions of the 1999 constitution is clear with regards to matters relating to permanent incapacity of the President or Vice President; the point is made clear in Section 144(1)a \& b,(2),93) 7 (4) a \& b that the President's health condition must be confirmed by a panel of medical practitioners who shall certify same in a report which will be published in the official gazette of the government of the federation.

Between 23 November 2009, when President Yar'A duah was hurriedly taken to a specialist hospital in Jeddah, Saudi Arabia and 9 February 2010, when his Deputy Dr Good luck Jonathan, was by a Resolution of the Senate and the House of Representatives, declared acting President and Commander in Chief of the Armed Forces, the Nigerian polity experienced one of its greatest threats to the constitutional democracy and the rule of law.

While Section 144 expresses the permanent incapacity of the President or Vice President; Section .145 treats the circumstance by which the Vice President could act on behalf of the President in his absence Section 145 reads thus; Whenever the President transmits to the President of the Senate and the Speaker of the House of representatives a written declaration that he is proceeding on vacation or that he is otherwise unable to discharge the functions of his office, until he transmits to them on the contrary such functions shall be discharged by the Vice President as acting President.

The problem this creates is that due to the circumstance of the President's ill health, he was unable to transmit to the Senate President and the Speaker of the House of Representatives the required written declaration to his intention. As a result, there was confusion in the polity. 
Should the Vice President go ahead and assume office as President? Should he continue to wait for the return of the President, or perhaps his recovery? If the latter option is considered, what would be the implication of this for the State?

Since accurate information on President Yar'A duah's sickness was in short supply, the rumor mill gained the upper hand. Thus, public reaction to a news report in the American Chronicle that Yar'A duah had died on 10th December 2009 quickly prompted a rebuttal by presidential spokesmen early January 2010.

President Yar'A duah's brief interview with BBC brought out long a subdued anger laced with cooling proverbs and philosophy. "The truth is like oil. No matter how much water you pour on it, it will surely float to the top. One day the truth will come out" (BBC 2010).

At a public rally led by noble laureate Professor Wole Soyinka in Abuja following the same BBC interview, angry demonstrators spoke out before members of Nigeria's House of Representatives .One of these was an activist Najatu Mohammed, who explained that the issues at stake was not Yar'A duah's statement on the $\mathrm{BBC}$, that the issue was that he has abdicated without leave, without permission, so this calls for his impeachment. Yar'A duah is paid by the federal Republic of Nigeria, he is accountable! (BBC 2010).

At the same Abuja rally, Nigerian Pastor Tunde Bakare re-echoed what Najatu Mohammed said "Everyone, east, north, west and south of our country should take these words home. The Presidency is not a birth right. The presidency is a constitutional office. President Yar'A duah is not fit to occupy that office. Therefore, Umaru Yar'Adua go home" (Nigerianmuse2010).

This solemn assembly is not for the sake of Jonathan Good luck, it is for the sake of good Governance. Enough is Enough! (Nigerianmuse, 2010).

The position of the Ohaneze Ndigbo a pan Igbo socio- cultural organization on the State of the Nation came out in a public statement in early February 2010.In it, its president General, Ambassador Ralph Uwechue, said;

Ndigbo call on all Nigerians to realize that the way and manner the issue of the president' $s$ absence in relation to the status of the Vice President is currently handled puts the Constitution of the federal republic of Nigeria into jeopardy. Ndigbo (Igbo People) urge all Nigerians to note that whatever puts the constitution in jeopardy puts the nation in jeopardy. All steps must now be taken urgently to put an end to this machination to put the constitution and the integrity of the nation in jeopardy (Punch 2010).

Uwechue said that Ohaneze urges all Nigerian to step forward now and make sure that the position and prestige of the Vice President as provided in the constitution of the federal Republic of Nigeria is not diminished or undermined (Punch 2010).

As President Yar'Aduah's BBC interview failed to provide some adequate balm for frayed political nerves, rumors helped to spread more and more wild fires nationwide. The kinsmen of the Vice President Dr Good luck Jonathan, took the bull by its horn.

In a statement entitled "NigerDelta warns against setting Nigeria on fire", the Ijaw Monitoring Group (IMG)(a group from Dr Jonathan 's ethnic extraction) gave the rest of civil society some inkling of what bothered their minds.

Moreover, to the surprise of stakeholders in civil society, President Yar'Adua, as sick as he was in Jeddah took a midnight flight and arrived at the International Airport, Abuja, on 24 February 2010, under cover of darkness with his Brigade of Guards present to salute their commander- in -Chief .Meanwhile none of that succession of events was known to Dr Jonathan, appointed acting President on February 2010.

Pro Jonathan group were miffed by that military arrangement while others on the side of President Yar "Adua rejoiced. The serious implications of this clash of interest alarmed other stakeholders at home and abroad. Even so, it was in clear conflict with sections 1(3) of the 1999 constitution which specifically stipulates; If any other law is inconsistent with the provision of this constitution, this constitution shall prevail and any other laws hall to the extent of the inconsistency be void. More over President Yar"Adua, though very sick remained Commander- in- Chief of the Armed Forces a tittle 
also assumed by Dr Jonathan as Acting President . Hence, any attempt to justify that illegal duality as de jure and defacto Commander- in-Chief, flouted both the letter and spirit of the 1999 constitution.

Besides, in the context of Nigerian cultural precepts and practice , any human being with two "heads" is a clear abnormality or abomination. Translated in the political arena, what Nigeria had at the level of headship, silently from 23 November,2009 and openly from 9th February 2009 was the constitutional equivalent of an abomination no more and no less (Tamuno,2012).

Against the back drop of President Yar'Adua's condition, as of 9th February, 2010, at least two remedies, potentially available months later, were not quickly taken.

First, relevant aspects of this case, were not taken to the level of the Supreme Court and so did not resolve the pending matter authoritatively within its powers. Second a complete appeal of section 144 of the 1999 constitution was not taken to its logical conclusion and so did not end the matter in an orderly manner for the removal of Nigeria's de jure Commander in Chief. But not all subsisting doubts would have been removed, yes in the minds of several close friends of President Yar 'Adua and co- defenders of his cause for whatever reason.

\subsection{The Case of Waziri Tambuwal's Defection}

A major gap in the Nigerian constitution was revealed in the case of former Speaker of the House of Representatives Aminu Waziri Tambuwal who around October 2014, had defected from the People's Democratic Party (PDP)to the opposition All Progressives Congress(APC).This action spawn a round of controversy in the polity in view of its implication. Is the trend healthy for the political development of Nigeria? Does it portend stability for a political party. Does the law regulating political parties' activities allow such defection? What actually is the position of the law on the subject matter?

Badejo and Obah -Akpowoghagha (2015) observed that section 68(1)(g)of the 1999 constitution is clear on the fate of a member of the Senate or House of Representatives who decamps from one party to another. Such member loses his seat by implication. It reads inter alia;68(1)A member of the senate or of the House of Representative shall vacate his seat in the house of which he is a member if (g)being a person whose election to the house was sponsored by a political party, he becomes a member of another political party before the expiration of the period for which that House member was elected: Provided that his membership of the latter political party is not as a result of a division in the political party of which he was previously a member or of a merger of two or more political parties or factions by one of which he was previously sponsored. However, the claims by politicians is the right to freedom of association

Eme \& Ogbochie(2014)argued that there were provisions in the in the 2010 Electoral Act to check persistent cross carpeting from one political party to another, providing conditions for defection of elected officer however constitutional loopholes are exploited by politicians for their own selfish ends. Though the constitution guarantees freedom of association but the flimsy excuse politicians give for their defection is a source of concern and it is inimical to the development of democracy.

Ogunbodeded on (2015) observes that cross carpeting has become a norm in the eyes of political actors, every executive seems tenable and every step taken is a means of outwitting opposition parties. He reasoned that Tambuwal may have taken the decision for his political survival the aftermath of that action led to the removal of his security details by the Inspector General of Police(IGP)Suleiman Abba.

The IGP ought to have known that Section 40 of same constitution states that; every person shall be entitled to assemble freely and associate with other persons and in particular he may form or belong to any political party, trade union or any association for the protection of his interest

According to Flava (2014), the President of the Nigeria Bar Association Alegeh Senior Advocate of Nigeria (SAN), attributed the leadership crisis in the Federal House of Representatives over the defection of the Speaker, Aminu Tambuwal to constitutional loopholes and ineffective administration of justice leading to the withdrawal of Tambuwal's security aides by the Nigerian police.

Alegeh explained that the constitution never envisaged such political scenario such as the defection of either the Speaker or Senate President from one party to the other since both officers were meant to preside in the House among other law makers (Flava 2014). 
He argued that the police erred by withdrawing the security details of the Speaker as it had no constitutional powers to determine whether Tambuwal's defection was constitutional or not (Flava 2014).

This political twist occasioned by the gap created in the Nigerian constitution was worsened by the poor intervention of the court in dealing with such constitutional lacuna. The role of the court in matters of constitutional defects is very critical. It is important for the court to always act in order to uphold democracy.

Alegeh also described as unacceptable the pending court cases of some People's Democratic Party(PDP) lawmakers who decamped to the APC, which he said lasted for an upward of eight months in court, noting that the argument surrounding Tambuwal's defection would not have arisen, if such cases had been constitutionally resolved(Flava 2014).

\subsection{The Case of the Death of Abubakar Audu and Constitutional Gap}

Another constitutional lacuna became evident shortly after the demise of the APC governorship aspirantin Kogi State North Central Nigeria, Abubakar Audu. Audu was on the lead in the election against the incumbent Governor of the State, Idris Wada of the Peoples Democratic Party (PDP )by41,353 votes during the election. The Independent National Electoral Commission(INEC)Nigeria s electoral umpire, however, declared the election inconclusive as votes from the 91 cancelled polling units $(49,953)$ was higher than the margin between the two leading candidates( Isine and Tukur,2015).

Mr Audu would have eventually emerged winner after elections were heldin the 91 polling units as the PDP candidate would have needed100percent turnout and about all the votes for his party to emerge victor (Nairaland 2015).

Indeed prio to celebration of his victory, the APC candidate died, which resulted in constitutional crisis. The most constitutional approximation that links to the incident is Section 181 which observes that: ( 1 In the case of death of a candidate elected governor prio to taking of the Oath of Allegiance and of office, is unable for any reason whatsoever to be sworn in ,the person elected with him as Deputy governor shall be sworn in as governor and he shall nominate a new deputy governor who shall be appointed by the Governor with the approval of a simple majority of the house of Assembly of the State and (2) in case of death of a person elected as governor or Deputy governor of a State or if such person is unable to assume office before the inauguration of the House of Assembly ,the independent national Electoral Commission(INEC) shall immediately conduct an election for a Governor and Deputy governor of the State.

However as stated by Adbul Mahmud, a constitutional lawyer, the section only refers to duly elected candidates ( Isine and Tukur,2015).

With INEC declaring the Kogi election in conclusive, it was seriously debated whether Mr .Audu could be considered duly elected. According to the Residential Electoral Commissioner (REC), Mr. Mahmud argued that they were in a strange legal territory stating that The 1999 constitution and the Electoral Act do not envisage the unfortunate circumstance that Audu's death foists (Kadiri2015). INEC had declared Saturday poll inconclusive, which makes Section .181(1) CFRN 1999 irrelevant (Kadiri, 2015).

A fresh poll appears unnecessary. Section 36(1)of the Electoral Act 2011 empowers INEC to Countermand (cancel) the poll for the 91 polling units it had earlier announced and fix a new date for the poll within 14 days(Isine and Tukur,2015). The effect of this section is that the power of countermand can only be exercised on the death of a candidate and after nomination paper has been filed. The poll for the 91 polling units is not a fresh poll; it is the same November 21 poll. So, what happens to the APC? Section 33 of the Electoral Act 2011 allows the party to substitute the dead candidate. Under this section, substitution can only be allowed when a candidate dies or withdraws (cited in Isine and Tukur, 2015).

Section 36(1)of the Electoral Act ,to which Mahmud referred talks about the death of a candidate before an election; If after the time for delivery of nomination paper and before the commencement of the poll, a nominated candidate dies, the chief national Electoral commissioner or the Residential 
Electoral commissioner shall, being satisfied of the fact of the death, countermand the poll in which the deceased candidate was to participate and the Commission shall appoint some other convenient date for the election within 14 days.

In the Kogi case, the poll had already commenced and was on the verge of conclusion. A constitutional lawyer, asked INEC to conduct supplementary election and declare a winner rather than cancellation of the election because of Audu's death (Isine and Tukur, 2015).

According to him,: The way forward is that the election will be concluded and a winner will be declared. One can hastily opine that the election will have to be cancelled because Audu, who was a leading candidate is dead and that the election be conducted afresh: (cited in Isine andTukur,2015).

In 1999 in Adamawa state when Atiku Abubakar was elected governor and thereafter, Obasanjo picked him as a Vice Presidential candidate thereby making his position vacant which resulted in a legal battleis a clear reference. The Supreme Court in that case held that the deputy governor elect will step into Atiku's position and that no new election was required. INEC in that instance was arguing that the governor elects as not dead but was no longer available and the Supreme court countered that argument. In the present case, since the winner has not been declared and the certificate of return has not been issued, MrOgunye that there is no clear difference with what happened in Adamawa State. Constitutional lawyers are of the view that the election cannot be cancelled at this time because Audu is dead, arguing that he did not die on the eve of the election but when the election was almost concluded.

Other observers considered the possibility of relying on the Supreme court ruling that made Rotimi Amaechi the River State governor in 2007 wherein Nigeria's apex court ruled that it was PDP that was present on the ballot that won the election; and that having declared Mr Amaechi the true candidate of the PDP, he should be sworn in as Governor. Mr Amaechi subsequently replaced Celestine Omehia who had occupied the seat having been the one the PDP initially recognized as its candidate in the election.

The current challenge points to a gap in the constitution and the electoral law. Two factors can avert a future occurrence of the Kogi crisis. The first is for the parties to the dispute to go to court. The court will either make a pronouncement, especially on the constitutional interpretations or give a ruling that will become a precedent. The second is constitutional review or an amendment to the Electoral Act that will make a provision for what should be done, if a candidate dies when the election is inconclusive.

\section{CONCLUSION}

Arguably a lot of problems arise from the 1999 constitution. Going by the history of the 1999 constitution which is largely described as a military invention emerging from decree 24 of 1999. As discussed, issues emanating from the constitution reveal that actual practice of the constitution is far from what the document makes provision for.

As it is expected, no body of laws is quite capable of addressing all maters in a political society (Ezra 1964;Dudley 1978). While noting that constitutions must be forward-looking to capture future events, it will always require some fine tuning from time to time as events unfold. From the analysis of this review, it is imperative to state that the loopholes created in the constitution have derailed democracy deepening, particularly such gaps have been a lee way for politicians to commit impunity which invariably distorts peace and sustainable economic and political development of Nigeria.

These bizarre political events will have a long term effect on the coming generations and particular their understanding and adherence to constitutional dictates. This compels the critical need to redress this enormous challenge. The Nigerian constitution contains several provisions that make it a stumbling block for consolidating democracy. in view of this challenge, it is therefore recommended that there is need to review the 1999 constitution. It must reflect present realities. Also, the court which is seen as the last hope of the common man, should adjudicate on infringement on these letters in our statutory book. Thus, constitutionalism which has been an integral part of democratization has been largely missing in the Nigerian constitution this calls for urgent policy attention. 


\section{REFERENCES}

Akande J (1982).Introduction to the Nigerian constitution London :Swet and Maxwell Press

Barkun, M (2003). A Culture of Conspiracy: Apocalyptic Visions in Contemporary America. University of California Press.

Basham, L (2011). "Conspiracy Theory and Rationality". In Jensen, Carl; Harré, Rome. Beyond Rationality. Newcastle on Tyne: Cambridge Scholars Publishing.

Badejo B and Obh -Akpowoghagha ,N (2015).The impact of cross carpeting and multiplicity of Political parties in nigeria democratic process journal of African Studies and development7(98),215-230

BBC News(2010) - Nigeria's ailing President Yar'Adua breaks silence Retrieved from news.bbc.co.uk/2/hi/africa/8453321.stm on 20-3-2015

Bello A (2000).Memorandum of the Elder Moro to the presidential technical committee for review of the 1999 constitution

Bello -Immam,IB \& Obadan M (eds;)(2004).Democracy government and Development in Nigeria's Fourth Republic 1999-2003.Ibadan :Centre for Local Government and Rural Development Studies

Dudley B (1978).Instability and Political Order: politics and crisis in Nigeria Ibadan: Ibadan University press

Eme O and Ogbochie A (2014).The legal /constitutional basis of political party defection in Nigeria Kuwait chapter of the Arabian journal of business and management Review,3(11),19.

Ezra K (1964).Constitutional development in Nigeria Cambridge University Press

Federal Ministry of Information (1963).Constitution of the Federal Republic of Nigeria 1963 Lagos Federal Government press

Federal Ministry of Information (1979).Constitution of the Federal Republic of Nigeria 1979 Lagos: Federal government press

Federal Ministry of Information (1999). Constitution of the Federal Republic of Nigeria 1999 Lagos: Federal Government Press

Flava C (2014) Constitutional loopholes to blame over Tambuwal's crisis Retrieved from http:// campusflava.com/articles/constitutional-loopholes-blame-over-tambuwal\%E2\%80\%99s-crisis 20-7-2015

Ikime O (ed;) (1980).Groundwork of Nigerian History Ibadan: Heineman Educational Books Nigeria PLC

Isine I and Tukur,S (2015). Kogi Election and Abubaka Audu's death:What lawyers and the Law Say Monday ,November 23,2015 http:www.premiumtimesng.com/news/193764-kogi election -and abubalaraudus-death-what lawyers-and -the -law-say.html.Retrieved 11/12/2015

Kadiri I (2015)Kogi guber poll: The unfolding scenarios Champion Newspapers Retrieved from http://www.championnews.com.ng/kogi-guber-poll-the-unfolding-scenarios/ 5-5-2016

Nairaland (2015).Death of APC Kogii Guber Candidate Exposes Loophole In Nigerian constitution politics nairaland Retrieved 10/12/2015

News 7 Nigeria (2015). "Big confusion In Kogi state Election: The Way Forward"on November 30,2015http://www.new7ng.com/2015/11/big-confusion-in-kogi-state-election-the forward/ retrieved on 12/12/2016

Nigerianmuse (2010) Thousands Join Soyinka, Falana, Bakare, Galadima ... - NigerianMuse Retrieved from www.nigerianmuse.com/.../nigeria.../thousands-join-soyinka-falana-bakaregaladima 10-5-2015

Odondri P(2004) Constitutioal Development of Nigeria Lecture Notes Department of Political and Administrative Studies University of Port Harcourt Nigeria

Ogbodo C (2010). The emergence of A Patriot President Goodluck Jonathan GCFR taking Nigeria to Greater heights Ibadan Centre for General African Studies Research and Documentation

Ogunba O( ed;)(1997) .Governance and the Electoral process: Nigeria and the United States of America Lagos: American Studies Association of Nigeria. 
Ogunbodedeon G (2015).Blocking Constitutional loopholes. The Nation newspaper January 222015 available at http://thenationonlineng.net/blocking-constitutional-loopholes retrieved 2/12/2015

Mottoh -Migan V (1994).constitution I Post independence nigeria: A critique Ibadan :Spectrum Books

Nwabueze B (1982).The presidential constitution of nigeria London :Hurst and Co

Odondri P(2004). The making of a nation Stages in Nigeria's constitutional development Port Harcourt :Amethyst \& Colleagues publishers

Olakanmi and Co(2004).The Nigerian constitutions: A Compendium Abuja:Lawlords Publications

Popper, K (1945). Open Society and Its Enemies, Book II. London: Routledge and Kegan Paul.

Tamuno T (2012)Stakeholders at War in Nigeria :from Lord Lugard to President Good Luck Jonathan.Oyo: Stirling horden publishers Ltd

The Punch, (2010). THE ROLE OF OHANEZE IN FOSTERING NATIONAL UNITY . 7th Feb. 2010 Retrieved fro wwwpunch online newsorg 10-6-2014

Udoma U (1994).History and Law of the Constitution of Nigeria Lagos: Malthouse Press

Wood, G ( 1982) .Conspiracy and the paranoid style: causality and deceit in the eighteenth century." William and Mary Quarterly 39 N3: pp402-441. 